\title{
FZR1 wt Allele
}

National Cancer Institute

\section{Source}

National Cancer Institute. FZR1 wt Allele. NCI Thesaurus. Code C150237.

Human FZR1 wild-type allele is located in the vicinity of 19p13.3 and is approximately 32 $\mathrm{kb}$ in length. This allele, which encodes fizzy-related protein homolog protein, plays a role in cell cycle-specific ubiquitination. 